\title{
The vulnerability analysis of catchment areas using rapid assessment method (case study in Universitas Indonesia, Depok)
}

\author{
Eva Rolia $^{1 *}$, Dwita Sutjiningsih ${ }^{1}$, and Fitria Fitria ${ }^{1}$ \\ ${ }^{1}$ Civil Engineering Department, Faculty of Engineering, Universitas Indonesia, Depok, Indonesia
}

\begin{abstract}
Catchment area of aquatic system in Universitas Indonesia (UI) campus has a function as groundwater recharge for Depok area, which is the buffer zone of Jakarta. This catchment area has high level of imperviousness as a consequence of increasing population. The high imperviousness implicates in the degradation of the catchment area health. For that reason, the vulnerability assessment of UI catchment area is needed to arrange of restoration recommendation. This research applies Rapid Assessment Method which implements eco-hydrological concepts including aquatic and riparian condition as well as imperviousness of catchment area. Locations of the research are Kenanga and Agathis catchments area. The result of initial classification based imperviousness both catchment areas are categorised as NonSupporting, where the imperviousness of Kenanga and Agathis is $31,0 \%$ and $77,18 \%$ respectivelly. Based on the assessment on aquatic and riparian condition as well as future land use, the final classification of both catchment areas is Restorable Non-Supporting catchment area.
\end{abstract}

\section{Introduction}

The availability of water resources in terms of quantity and quality tends to be critical and become a worldwide problem [1]. Sustainability of water resources is determined by watersheds functioning as catchment areas. Since watersheds are formed by inseparately ecosystem interaction from upstream to downstream, the healthiness of catchment areas is important to be considered. It can be done by measuring the quality of the water located in water bodies which are parts of catchment areas such as lakes, rivers, and others. [2] stated that catchment areas damage indicators could be recognised by hydrological behaviour shifts such as high frequency of flood, more erosion and sedimentation, as well as decreasing water quality. Therefore, catchment area management should be done through sustainable natural resource utilisation [3].

Human activities and the needs of space implicate on land covering conversion from pervious to impervious cover. Increasing number of impervious land covering strongly affected on the change of water quality and ecosystem especially for small scale catchment areas within $13-77 \mathrm{~km}^{2}[4,5]$. Excessive impervious land covering brought bad impacts on the healthiness of catchment areas [6].

This paper will discuss the vulnerability assessment of catchment areas in UI campus namely Kenanga and Agathis using Rapid Assessment Method. Both catchment areas are characterised by education and residential uses. Estimates of impervious cover using
GIS technology by digitizing land cover features, water quality data [7] and aquatic [8] used derived from previous studies [9]. The result of this study is expected to be a foundation to formulate necessary recommendations which finally aim to do conservation and increase environmental carrying capacity of UI campus and surrounding areas.

\section{Methodology}

\subsection{General Description of the Study Area}

Kenanga catchment area is astronomically located in $106^{\circ} 49^{\prime} 44,66^{\prime \prime}-106^{\circ} 49^{\prime} 51,51^{\prime \prime}$ East Longitude and $6^{\circ} 21^{\prime} 56,96 "-6^{\circ} 22^{\prime} 04,64 "$ South Latitude. Meanwhile, Agathis catchment area is located in $106^{\circ} 49^{\prime} 28,47^{\prime \prime}-$ $106^{\circ} 49^{\prime} 29,69^{\prime \prime}$ East Longitude and $6^{\circ} 22^{\prime} 5,75^{\prime \prime}$ LS$6^{\circ} 22^{\prime} 9,18$ " South Latitude.

\subsection{Analysis Procedure}

Watershed vulnerability assessment can be done by Tools 12 of Watershed Vulnerability Analysis proposed by Zielinski in 2002. This method aims to classify watershed condition. Furthermore, watershed vulnerability analysis basically illustrates eight steps to create planning for watershed, to figure sub-watershed out, to forecast land covering based on existing condition, and to identify factors causing a change on initial sub-watershed classification. There are three 
basic steps which are initial classification, final classification, and priority scale formulation of restoration. In this research, initial classification was done by measuring impervious land covering using Geographical Information System (GIS). Then, final classification was done by assessing the existing condition of Kenanga pond and Agathis pond perimeters; and their projection as it was stated in the spatial planning of the city of Depok, West Java Province. To be more detail, the stages can be seen through this following figure.

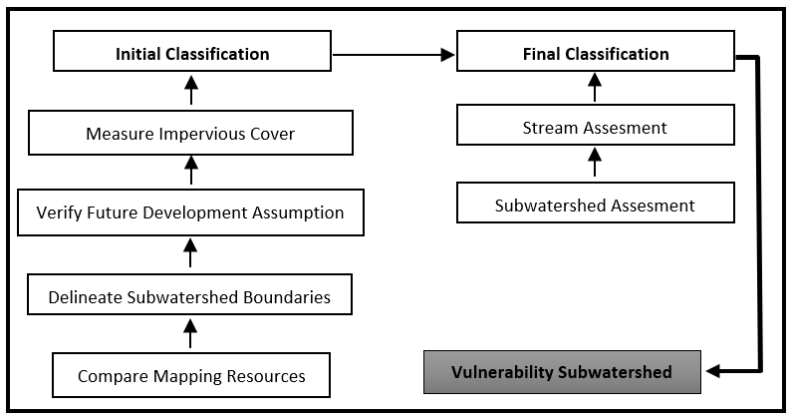

Figure 1. Steps of catchment area vulnerability assessment [4]

\section{Result and Discussion}

\subsection{Initial Classification of Catchment Area}

Initial classification of the catchment area was done by measuring land covering in the catchment area. This is important since impervious cover is one of dominant factors influencing the healthiness of catchment areas. Increasing number of impervious cover indicates development that occurred in the area. Direct measurement is considered as the most accurate method among various techniques. However, using Geographical Information System (GIS) is considered as the most efficient method [10,11]. These following figures illustrate impervious cover in Kenanga catchment area (A1) and Agathis catchment area (A2). This study uses ArcGIS 10.1 software by digitizing land cover features such as roof, asphalt road, concrete road, and then visual interpretation.

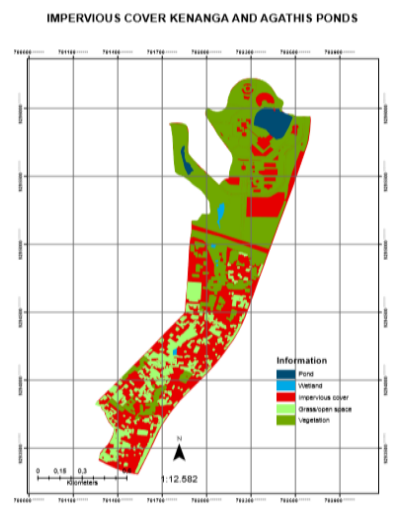

Figure 2. Existing condition of impervious cover of Kenanga (A1) and Agathis (A2) Catchment Areas
Furthermore, the percentage of impervious land covering was calculated as presented by this following table.

Table 1. The Percentage of Impervious Cover

\begin{tabular}{|c|c|c|c|c|}
\hline No. & $\begin{array}{c}\text { The Name } \\
\text { of } \\
\text { Catchment } \\
\text { Area }\end{array}$ & $\begin{array}{c}\text { Total Area of } \\
\text { Impervious } \\
\text { Cover (Ha) }\end{array}$ & $\begin{array}{c}\text { Total } \\
\text { Catchment } \\
\text { Area (Ha) }\end{array}$ & $\begin{array}{c}\text { Percentage } \\
(\%)\end{array}$ \\
\hline 1. & Kenanga & 16,84 & 54,67 & 31,0 \\
\hline 2. & Agathis & 61,998 & 80,33 & 77,18 \\
\hline
\end{tabular}

It is clearly seen that the percentage of impervious land covering reached $31,0 \%$ for Kenanga catchment area and $77,18 \%$ for Agathis catchment area. According to Impervious Cover Model developed by the Centre for Watershed Protection, Kenanga and Agathis can be categorised as "Non-Supporting" since the percentage exceeded $25 \%$; the model can be seen in figure 3 . It means that the water body cannot accommodate flood and the river undergo severe enlargement. In addition, the population of fish decrease significantly and the river cannot provide liveable habitat for insects. It also indicates bad quality of water and high level of bacteria. Biological water quality is also low and is dominated by insects and fish which are resistant to pollution. This following table shows the impervious cover model.

Table 2. The Impervious Cover Model [4]

\begin{tabular}{|c|c|c|}
\hline No. & $\begin{array}{c}\text { Impervious Cover } \\
(\%)\end{array}$ & Categories \\
\hline 1. & $0-10$ & Sensitive \\
\hline 2. & $11-25$ & Impacted \\
\hline 3. & $>25$ & Non Supporting \\
\hline
\end{tabular}

\subsection{Final Assessment of Catchment Areas}

Final Assessment of catchment area was conducted in the water body around perimeter. Criteria that were considered in this assessment included water quality, the population of rare plant species, and land cover in riparian [7,8]. [7] conducted water quality test on cascade-pond in UI by using WQI. The result of her measurement can be seen in these following tables. 
Table 3. The Result of Physical and Chemical Parameters Test on Kenanga Pond

\begin{tabular}{|c|l|c|c|c|c|}
\hline \multirow{2}{*}{ No. } & \multirow{2}{*}{$\begin{array}{c}\text { Parameter } \\
\text { (Unit) }\end{array}$} & \multicolumn{2}{|c|}{ Result } & \multirow{2}{*}{ Average } & Standard \\
\cline { 3 - 4 } & & Inlet & Outlet & & \\
\hline 1. & $\begin{array}{l}\text { Total } \\
\text { Suspended } \\
\text { Solid (mg/L) }\end{array}$ & 67,5 & 19,20 & 43,5 & 50 \\
\hline 2. & $\begin{array}{l}\text { Turbidity } \\
(\text { NTU) }\end{array}$ & 5,11 & 2,66 & 3,88 & 25 \\
\hline 3. & pH & 6,19 & 6,37 & 6,28 & $6,5-9$ \\
\hline 4. & BOD (mg/L) & 3,0 & 0,26 & 1,63 & 3 \\
\hline 5. & DO (mg/L) & 3,39 & 5,61 & 4,5 & 5 \\
\hline 6. & Temperature & 30,4 & 30,5 & 30,45 & $\begin{array}{c}\text { Deviation } \\
{ }^{\circ} \mathrm{C}\end{array}$ \\
\hline
\end{tabular}

Table 4. The Result of Physical and Chemical Parameters Test on Agathis Lake

\begin{tabular}{|c|l|c|c|c|c|}
\hline \multirow{2}{*}{ No. } & \multirow{2}{*}{$\begin{array}{c}\text { Parameter } \\
\text { (Unit) }\end{array}$} & \multicolumn{2}{|c|}{ Result } & \multirow{2}{*}{ Average } & \multirow{2}{*}{ Standard } \\
\cline { 3 - 4 } & & Inlet & Outlet & & \\
\hline 1. & $\begin{array}{l}\text { Total } \\
\text { Suspended } \\
\text { Solid (mg/L) }\end{array}$ & 6,10 & 5,50 & 5,80 & 50 \\
\hline 2. & $\begin{array}{l}\text { Turbidity } \\
\text { (NTU) }\end{array}$ & 1,68 & 0,86 & 1,27 & 25 \\
\hline 3. & pH & 6,14 & 6,20 & 6,17 & $6,5-9$ \\
\hline 4. & BOD (mg/L) & 1,10 & 1,60 & 1,35 & 3 \\
\hline 5. & DO (mg/L) & 2,43 & 1,79 & 2,11 & 5 \\
\hline 6. & Temperature & 29,30 & 27,60 & 28,75 & $\begin{array}{c}\text { Deviation } \\
{ }^{\circ} \mathrm{C}\end{array}$ \\
\hline
\end{tabular}

Table 3 and 4 above show that water quality based on Physical and chemical parameters of Kenanga and Agathis ponds are still in the standard interval except $\mathrm{pH}$. UI cascade-pond damage due to levels of excessive pollutant solute resulted in decreased water quality, reduced aquatic animals and border ecosystems [8]. Some parameters have been tested to investigate pollutant indicators in UI cascade-pond [9]. Those parameters are BOD, COD, Ammonium, and Phosphate which exceeded the standard interval. In addition, these results were strengthened by the result of Pinasti's research conducted in 2017 as it was shown in table 3 and 4, which explains that the Kenanga pond is heavily polluted and polluted on moderate in Agathis pond.
In addition to researching water quality, riparian zones were also observed about existing plants around it. The function of the riparian zone is the ecological function that is as a food source, as a nutrient filter, and habitat [12]. As a habitat, riparian zones affect the abundance of macroinvertebrates. Riparian buffer zones can significantly reduce the impact of deforestation on tropical flows. Macroinvertebrates are animals sensitive to existing pollution.

Furthermore, final classification of Kenanga and Agathis based on the assessment of river corridor and land use is categorised as Restorable Non-Supporting Watershed. This is because both lakes still have five assessment criteria of riverbank and two assessment criteria of sub-watershed scale. Some indicators show Kenanga and Agathis catchment areas can be classified as vulnerable catchment areas because there is an increasing trend of impervious cover, polluted water, and the extinction of some water plants. Moreover, future conditions of land cover were projected to decide appropriate rehabilitation efforts and priority scale of measures. The result of this projection is illustrated by these following figures.

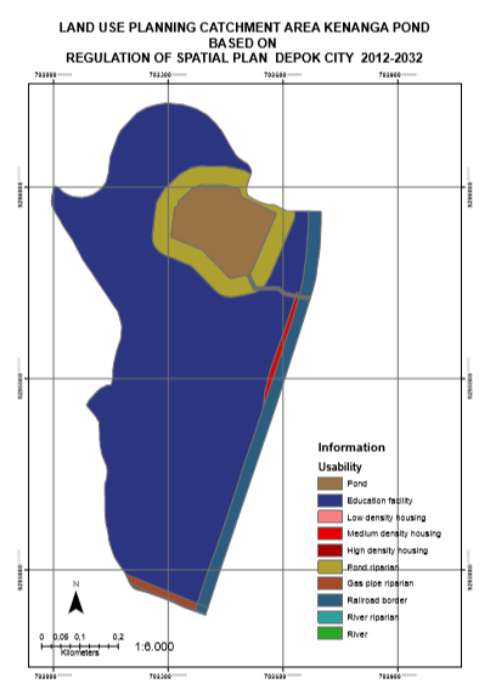

Figure 3. Spatial Planning Map of Kenanga Pond

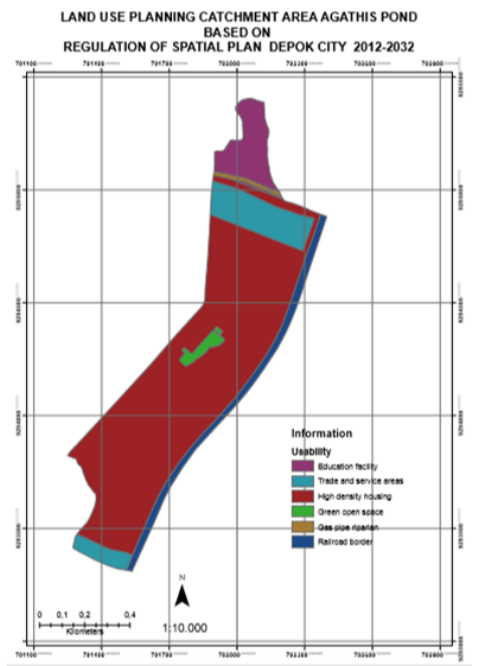

Figure 4. Spatial Planning Map of Agathis Pond 
These two figures show that both catchment areas are dominated by educational areas. Land use Agathis catchment area is also dominated by residential and commercial uses. According to the Spatial Planning of Depok City 2012-2023, development planning proposed in Kenanga catchment area is to develop educational and governmental facilities in UI campus. However, there are still some areas dedicated to green open spaces. Therefore, impervious cover decreases to $29,57 \%$. The same trend also occurs in Agathis catchment area. In this location, impervious cover decline to $73,48 \%$. To be more detail, the data is presented in Table 5 .

Table 5. The percentage of Impervious Cover Based on the Spatial Planning of Depok City 2012-2032

\begin{tabular}{|c|c|c|c|c|}
\hline No. & DTA & $\begin{array}{c}\text { Impervious } \\
\text { Cover (Ha) }\end{array}$ & $\begin{array}{c}\text { Large } \\
\text { of DTA } \\
\text { (Ha) }\end{array}$ & $\begin{array}{c}\text { Percentage } \\
\text { (\%) }\end{array}$ \\
\hline 1. & Kenanga & 16,16 & 54,67 & 29,57 \\
\hline 2. & Agathis & 59,02 & 80,33 & 73,48 \\
\hline
\end{tabular}

From the table above, it is estimated that up to 2032 there is a percentage of land cover with a downward trend, although only less than $5 \%$. It is possible there are restoration efforts made by the government based on Spatial Plans (RTRW) which has been made by the government of Depok City.

\section{Conclusion}

Based on rapid assessment conducted in this research, it can be concluded that Kananga and Agathis catchment areas is vulnerable. It is indicated by the percentage of both catchment areas, which are $31,0 \%$ in Kenanga and 78,18 in Agathis. Since the percentages are more than $25 \%$, the vulnerability classification can be categorised as Non-Supporting. From the existing condition of water quality, water biota, riverbank and the projection of impervious land cover, both Kenanga and Agathis catchment areas can be classified as Restorable NonSupporting. The estimated is a decrease in percentage of land cover $(<5 \%)$ from the GIS calculation of 2017 condition compared with the condition according to RTRW Depok City 2012-2032.

\section{Acknowlegment}

I am very grateful to Universitas Indonesia for the International Publication Grant (PITTA 2018) funding No. 2422/UN.2.R3.1/HKP.05.00/2018, Universitas Muhammadiyah Metro for the cooperation. I would also like to thank to Water Resource Management Master Students, Mas Ardi, Mas Dwi, and Sugi for all your supports.

\section{References}

1. Asdak, Hidrologi dan Pengelolaan Daerah Aliran Sungai, Gadjah Mada University, (2002)

2. I. Mawardi, Kerusakan Daerah Aliran Sungai dan Penurunan Daya Dukung Sumber Daya Air di Pulau Jawa serta Upaya Penanganannya, Hidrosfir Indonesia Journal, 5, No. 2, 1-11, (2010)

3. Marlena. B, Kajian Pengelolaan sub-DAS Garang Hulu terhadap Kualitas Air Sungai, National Conference on Water and Environmental Resource Management, (2012)

4. J. Zielinski, Watershed Vulnerability Analysis, Center for Watershed Protection, (2002)

5. Schiff, Benoit, Effect of Impervious Cover at Multiple Spatial Scales on Coastal Watershed Streams, Journal of The American Water Resources Association, 43, 712-730, (2007)

6. Schueler, Is Impervious Cover Still Important? Review of Recent Research, Journal of Hydrologic Engineering, 14, (2009)

7. MF. Prinasti, Characteristic of Macroinvertebrates Abundance in Cascade-Pond System at Universitas Indonesia Campus, West Java, Indonesia, The 6th International Conference of Euro Asia Civil Engineering Forum (EACEF), (2017)

8. F. Zulkarnain, Cascade-pond System Health Assessment Based on Macroinvertebrate Indices and Its Relationship with Impervious Cover and Aquatic Buffer Zone in Urbanized Cathments, The 6th International Conference of Euro Asia Civil Engineering Forum (EACEF), Matec Web of Conferences 138, (2017)

9. D. Sutjiningsih, Water Quality Index for Determining The Development Treshold of Urbanized Catchment Area in Indonesia, International Journal of Technology, 8, No.1, 143157, (2017)8

10. S. Hamidreza, Spatiotemporal Vriation of Watershed Health Propensity through ReliabilityResielence-Vulnerability Based Drought Index (Case Study : Shazand Watershed in Iran), Science of The Total Environment, 587-588, 168-176, (2017)

11. Tiburan. Jr, Geospatial Based Vulnerability Assesment of an Urban Watershed, Procedia Environmental Science, (2013)

12. R. Naiman. H, The Ecology of Interfaces : Riparian Zones, Decamps, Annual Review of Ecology System, 28, 621 (1997)

13. Rencana Tata Ruang Wilayah (RTRW) 2012-2032, Depok City Government 